\title{
BACTERIOLOGICAL QUALITY OF HALFCOCKED CHICKEN MEAT PRODUCTS
}

\author{
Moustafa, N. Y. ", Tolba, K. SH. "' and Rania, H. EL-Shehawy" \\ "1 Food Control Dept., Fac. Vet. Med., Kafrelsheikh Univ., Egypt. \\ "Animal Health Research Institute, Mansoura Lab., Mansoura, Egypt. \\ Animal Health Research Institute, Giza Lab., Giza, Egypt. \\ 1 (raniahassan602@gmail.com)
}

\begin{abstract}
A total of 60 random samples of half cooked chicken meat products (chicken nuggets, chicken burger and chicken luncheon) were collected from different supermarkets at El-Dakahlyia, governorates (mansoura city) as 20 sample for each for bacteriological examination (These 60samples were analyzed and tested for total aerobic plate count, total enterobactracea count, total Staph count, total mold and yeast count, The presence of bacterial food pathogens was also evaluated in the examined sample ( $S$. aurous).The obtained results indicated that chicken Luncheon has high microbial count $6.6 \times 10^{7}$, for apc the lowest value was in Nuggets $3.6 \times 10^{6 .}$ This study offers determination of hygienic status, quality of chicken meat products heat treated. All recommendation to safe guard the consumer were discussed.
\end{abstract}

Keywords: Half cooked, Chicken meat, Bacteriology.

\section{INTRODUCTION}

Chicken and chicken meat products provide animal protein of high biological value for consumers at all ages, where they contain all the essential amino acids required for human growth, higher proportion of unsaturated fatty acids and less in cholesterol value. Moreover, Poultry 
meat products are highly desirable, palatable, digestible and nutritious for all ages. Further processing of poultry meat involves conversion of raw poultry carcasses into value added products e.g. reconstructed products, cold cuts or breaded products. Advantages of further processing of poultry meat are improving juiciness and flavor, shelf life and water holding capacity (Sahoo, et al. 1996).

Chicken, chicken meat products are good sources of animal protein of high biological value, which contain all the essential amino acids required for human nutrition, besides that they contain higher proportion of unsaturated fatty acids and less cholesterol especially when skin removed (Shedeed, 1999).

The acceptance of further processed chicken meat products depends upon overall acceptance, color, odour, taste and consistency. So, consumers had given much greater choice over the foods which are more selective, of high quality and cheap about the value of money. Finally, the products quality becomes more significant factor in meat products marketing (Potter, 2001andAgamy and Hegaz, 2011).

Aerobic plate counts in food samples may be useful to indicate quality, shelf life and post heat processing contamination (GuaranTek Analytical Labo- ratories, 2003).

Aswell as Total bacterial enterobacteriacae and fungal counts are considered as incidences of quality, which give an idea about the hygienicmeasures during further processing and help in assessing the keeping quality of further processed chicken meat products (Aberle et al., 2001).

$\overline{\text { Kafrelsheikh Vet. Med. J. Vol. } 14 \text { No. } 1 \text { (2016) }}$ 
Chemical analysis of further processed chicken meat products is greatly varied, so, tasting of the final products is a common practice in cooked and uncooked chicken meat products and applied to ensure the compliance of such products with the legal and composition of standards written on the label (Beckers, 1998).

Poultry products can be aroute of introduction of pathogenic bactericum. Therefore, the microbial content of these products should be minimized for consumption (Carvalho et al., 2005).

Food handlers are the primary source of S.aureus contamination in the processing plant. Most staphylococcal intoxications involving poultry products are related to recontamination of cooked product by food handlers, followed by improper holding temperature (NACMCF, 1997).

The consequences of contamination of food with bacterial pathogens can be particularly serious on many patients who may have impaired resistance to infection. Many hospital food handlers are probably not aware of the .tremendous threat they pose to patients (Aycicekctai, 2004a).

Personal hygiene may refer to the cleanliness of a person's body. The health of workers plays an important part in food sanitation. People are potential sources of microorganisms that cause illness to others through food poisoning.

Processing of poultry products requires a sever microbiological quality control, considering they are one of the main source of food born infections.Enterobactreacies family is agroup of bacteria that is used to asses the general hygienic status of food product (HPA, 2004). 
Cohen et al., (2007) Contamination of poultry meat by S.aureus can be occurred from different retail outlet sites and appliances such as cages, bleeding knife, drum, wooden log, cutting knife, polymesophiles, S. aureus and coliforms. The author reported that $80 \%$ of chicken burger were un acceptable on the base of Spain microbiological standards,concluded that the highest bacterial counts especially aerobic plate count and fecal coliforms in poultry meat products were recorded in hot season. The high levels of microbial contamination and occurrence of pathogens reflects the poor hygienic quality of poultry meat under these conditions.

BKhect et al., (2007) concluded the highest bacterial counts especially aerobic plate count and fecal coliforms in poultry meat products (chicken burger and chicken nugge 50 samples of frozen chicken nuggets and strips (25 of each) were examined microbiologically. The mean values of microbiological indices in the frozen chicken nuggets and strips for total aerobic plate counts $(\mathrm{cfu} / \mathrm{g}$ ) were $1.9 \times 105 \pm 4.7 \times 104 ; 7.4 \times 104 \pm 1.8 \times 104$; Enterobacteriaceae counts were $7.7 \times 102 \pm 2.1 \times 102 ; 1 \times 102 \pm 1.3 \times 10 ;$ Staphylococcus aureuscounts were $5.8 \times 103 \pm 1.2 \times 102 ; 3.4 \times 102 \pm 3.8 \times 10 ;$ ts $)$.

To ensure that the food is microbiologically safe, both the manipulators $(\boldsymbol{W H O}, 2002)$ and the food need to be continually monitored (Gilling et al., 2001).

Therefore, the objective of the current study was to , assess the hygienic states of some frozen poultry products by determine determine the level of APC, Staphylococci count, mold,yeast count and enterobactreacea count isolation and identification of staph from chicken meat products. 


\section{MATERIAL AND METHODS}

\subsection{Collection of samples:}

A grand total of 60 random samples of half cooked chicken meat products (20 each of chicken nuggets, chicken Burger and,lunchon) were collected from different supermarkets at ElDakahlyiagovernate, (mansoura city) The collected samples were transferred directly to the laboratory in an ice box under complete aseptic conditions without undue delay and then examined bacteriologically.

\subsection{Preparation of samples (USDA, 2011):}

The samples were prepared according to the technique recommended by (American Public Health Association "APHA" (1992) as follows, twenty five grams of the frozen half cooked chicken products were transferred to a septic blender jar and homogenized with $225 \mathrm{ml}$ of $0.1 \%$ sterile buffered peptone water for 1-2 minutes at 2000 r.p.m. to give an initial dilution of $1 / 10$.one $\mathrm{ml}$ of the initial dilution was transferred to another sterile tube containing $9 \mathrm{ml}$ of serial buffered peptone $(0.1 \%)$ to obtain the next dilution, from which further decimal serial dilutions were prepared

\subsection{Determination total of Aerobic Plate Count (APC) (ICMSF, 1978):}

It was done using standard plate count agar media.One $\mathrm{ml}$ from each of the previously prepared serial dilutions was aseptically poured into duplicate plates of sterile Petri dishes using pour plate method, then about $10 \mathrm{ml}$ of sterile melted tempered plate count agar were added and thoroughly mixed in horizontal position. After solidification, the inoculated as well as the control plates were incubated at $37^{\circ} \mathrm{C}$ for 48 hours in an inverted position. Plates with a range of 30 to 300 colonies were counted. The total aerobic 
2.5. Determination of Total Enterobacteacea Count (ICMSF, 1978):

From each of the previously prepared serial dilutions, 0.1 was spread over dry surface of duplicated plates of sterile Violet Red Bile Glucose (VRBG) agar. Then a cover layer (tempered to $45^{\circ} \mathrm{C}$ ) of approximately $5 \mathrm{ml}$ of VRBG agar were poured overall the plates . The inoculated and control plates were incubated in an inverted position at $37^{\circ} \mathrm{C}$ for $24 \mathrm{hrs}$. All purple suspected colonies surrounded by a purple halos were counted. Enterobacteriaceae count/g was calculated

\subsection{Determination of Total Mould and Yeast count (Cruickshank et} al., 1975):

One $\mathrm{ml}$ from each of the previously prepared serial dilutions was poured into duplicate Petri dishes using pour plate method of Sabouraud dextrose agar medium supplemented with chloramphenicol and chlorotetracycline $(100 \mathrm{mg} / \mathrm{L}$ of each) as described by Koburger and Farahat, (1975). The inoculated plates were incubated at $25^{\circ}$ Candexamined daily for presence of colonies. The total fungal count/g was calculated and recorded.

\subsection{Determination of total Staphylococci with isolation and} Identification of Staphylococcus aureus Staphylococcus aureus:

\section{Determination of Total Staphylococcus count: Difco Manual (1998):}

Ten grams of each sample were transferred into a flask containing $90 \mathrm{ml}$ of $0.1 \%$ sterile peptone water to get a dilution of $10^{-1}$, one $\mathrm{ml}$ of previous mixture was spreaded on mannitol salt agar (MSA) and Baird Parker's agar (BP) medium using a sterile glass rod. The inoculated Kafrelsheikh Vet. Med. J. Vol. 14 No. 1 (2016) 
plates were incubated at $37^{\circ} \mathrm{C}$ for $24 \mathrm{hrs}$; plates showing colonies from 30 to 300 were selected and counted. From each dilution $0.1 \mathrm{ml}$ was spread onto a dry surface of double sets of Baird parker agar plate (OxoidCM 275, SR54). Inoculated plates were incubated at $37^{\circ} \mathrm{C}$ for 48hours. Typical colonies ofS.aureus(back shining convex colonies, 1$1.5 \mathrm{~mm}$ in diameter with narrow whitemargin and surrounded by a clear zone extending into opaque medium) wereenumerated and the average number per gram was calculated (APH $\boldsymbol{A}, 1992)$.

The purified $S$. aureus isolates were identified through different biochemical tests[catalase test, coagulase test (tube test)] (Quinn, et al., 2002).

Mannitol salt agar medium was used to count Staph. aureusaccordingto thestaph. aureuswas determined using Mannitol salt agar mediaThe plates wereincubated at $35 \pm 2^{\circ} \mathrm{C}$ for 24 to $48 \mathrm{hrs}$.

\section{RESULTS AND DISCUSSION}

Table (1): Statistical analytical results of different bacterial counts (cfu/g) in examined chicken nuggets samples $(n=20)$

\begin{tabular}{|c|c|c|c|c|c|c|}
\hline \multirow{2}{*}{ Types of bacterial count } & \multirow{2}{*}{$\begin{array}{c}\text { No. of examined } \\
\text { samples }\end{array}$} & \multicolumn{2}{|c|}{ Positive samples } & \multirow{2}{*}{ Min } & \multirow{2}{*}{ Max } & \multirow{2}{*}{$\operatorname{Mean} \pm \mathbf{S E}$} \\
\hline & & No. & $\%$ & & & \\
\hline APC & \multirow{4}{*}{20} & 20 & 100 & $1 \times 10^{2}$ & $3.6 \times 10^{6}$ & $1.842 \times 10^{5} \pm 1.79 \times 10^{5}$ \\
\hline Yeast \& Moulds & & 20 & 100 & $2.7 \times 10^{2}$ & $6 \times 10^{5}$ & $3.073 \times 10^{4} \pm 2.99 \times 10^{4}$ \\
\hline Staph. aureus & & 6 & 30 & $<10$ & $7.8 \times 10^{3}$ & $4.14 \times 10^{2} \pm 3.89 \times 10^{2}$ \\
\hline Enterobacteriaceae & & 7 & 35 & $<10$ & $2 \times 10^{4}$ & $1.855 \times 10^{3} \pm 1.06 \times 10^{3}$ \\
\hline
\end{tabular}

NB: Negative Staph. aureus and Enterobacteriaceae counts $(<10 \mathrm{cfu} / \mathrm{g})$ were calculated in One Way Anova as zero count when applying statistical analysis.

$\overline{\text { Kafrelsheikh Vet. Med. J. Vol. } 14 \text { No. } 1 \text { (2016) }}$ 
Moustafa, N. Y. et., al.

Table (2): Statistical analytical results of different bacterial counts $(\mathrm{cfu} / \mathrm{g})$ in examined chicken burger samples $(\mathrm{n}=20)$

\begin{tabular}{|c|c|c|c|c|c|c|}
\hline \multirow{2}{*}{ Types of bacterial count } & \multirow{2}{*}{$\begin{array}{c}\text { No. of examined } \\
\text { samples }\end{array}$} & \multicolumn{2}{|c|}{ Positive samples } & \multirow{2}{*}{ Min } & \multirow{2}{*}{ Max } & \multirow{2}{*}{ Mean \pm SE } \\
\hline & & No. & $\%$ & & & \\
\hline $\mathrm{APC}$ & \multirow{4}{*}{20} & 20 & 100 & $1.5 \times 10^{2}$ & $4.3 \times 10^{7}$ & $2.188 \times 10^{6} \pm 2.15 \times 10^{6}$ \\
\hline Yeast \& Moulds & & 20 & 100 & $4 \times 10^{2}$ & $3 \times 10^{5}$ & $1.598 \times 10^{4} \pm 1.49 \times 10^{4}$ \\
\hline Staph. aureus & & 5 & 25 & $<10$ & $4.7 \times 10^{3}$ & $2.69 \times 10^{2} \pm 2.34 \times 10^{2}$ \\
\hline Enterobacteriaceae & & 8 & 40 & $<10$ & $8.3 \times 10^{5}$ & $4.577 \times 10^{4} \pm 4.1 \times 10^{4}$ \\
\hline
\end{tabular}

NB: Negative Staph. aureus and Enterobacteriaceae counts ( $<10 \mathrm{cfu} / \mathrm{g})$ were calculated in One Way Anova as zero count when applying statistical analysis.

Table (3): Statistical analytical results of different bacterial counts (cfu/g) in examined chicken luncheon samples $(n=20)$

\begin{tabular}{|c|c|c|c|c|c|c|}
\hline \multirow{2}{*}{ Types of bacterial count } & \multirow{2}{*}{$\begin{array}{c}\text { No. of examined } \\
\text { samples }\end{array}$} & \multicolumn{2}{|c|}{ Positive samples } & \multirow{2}{*}{ Min } & \multirow{2}{*}{ Max } & \multirow{2}{*}{ Mean \pm SE } \\
\hline & & No. & $\%$ & & & \\
\hline APC & \multirow{4}{*}{20} & 20 & 100 & $2.9 \times 10^{2}$ & $6.6 \times 10^{7}$ & $3.311 \times 10^{6} \pm 3.29 \times 10^{6}$ \\
\hline Yeast \& Moulds & & 20 & 100 & $4 \times 10^{2}$ & $3 \times 10^{5}$ & $1.572 \times 10^{4} \pm 1.49 \times 10^{4}$ \\
\hline Staph. aureus & & 4 & 20 & $<10$ & $4.7 \times 10^{3}$ & $2.59 \times 10^{2} \pm 2.34 \times 10^{2}$ \\
\hline Enterobacteriaceae & & 7 & 35 & $<10$ & $1 \times 10^{5}$ & $5.127 \times 10^{3} \pm 4.99 \times 10^{3}$ \\
\hline
\end{tabular}

NB: Negative Staph. aureus and Enterobacteriaceae counts ( $<10 \mathrm{cfu} / \mathrm{g})$ were calculated in One Way Anova as zero count when applying statistical analysis.

It is evident from the results recorded in table (1) that the APC $(\mathrm{cfu} / \mathrm{g})$ in the examined samples of half cooked chicken meat products varied from $2.9 \times 10^{2}$ to $6.6 \times 10^{7}$ with a mean value of $3.311 \times 10^{6} \pm$ $3.29 \times 10^{6}$ for chicken lunchon $1.5 \times 10^{2}$ to $4.3 \times 10^{7}$ with a mean value of $2.188 \times 10^{6} \pm 2.15 \times 10^{6}$ fo chicken burger, and $1 \times 10^{2}$ to $3.6 \times 10^{6}$ with a mean value of $1.842 \times 10^{5} \pm 1.79 \times 10^{5} \mathrm{cfu} / \mathrm{g}$ for chickennuggets, 
Bacteriological examination of chicken meat products clearly indicated that the chicken nuggets samples had significantly higher bacterial load than either lunchon or ,burger nearly similar results was observed in El-Hoti et al., (2011); while Osman, (1997 \& 2001) and Sofroni et al., (2008) recorded higher mesophilic counts for frozen chicken products. The aerobic plate count gives an idea about the hygienic measures applied during processing and also help in the determination of the keeping quality of the product. The highly aerobic count indicates contamination of raw material or unsatisfactory processing as well as it may be due to unsuitable environmental condition during storage (ICMSF, 1978b) (Heat treated) chicken products samples or due to the fluctuations in storage temperatures. Higher values were observed in ELShora, (1990) who found that the log mean values of of total Aerobic counts of lunchon ,burger are $1 \times 10^{3}$ and for frozen chicken products and Abd EL-Magied-Walaa, et al., (2009) who found the psychrotrophic count was $1.43 \times 10^{5} \pm 0.37 \times 10^{5} / \mathrm{g}$ in breast samples and $4.28 \times 10^{6} \pm 0.38 \times 10^{6} / \mathrm{g}$ in wings. In contrast lower values were reported by Zaki-Nadia. Furthermore, the contaminated The obtained results in APC come inaccordance with those reported by Osman-Eman (2001) and Bkheet et al. (2007) forchicken nuggets and Shaltout (2006) forchicken burger. Lower APC in chickennuggets obtained by Osman -Eman (1997) and Al-Dughaym and Altabari (2010). Thehigh total aerobic mesophilic plate countmight be attributed to the contamination ofthe product from different sources or unsatisfactoryprocessing as well as it may bedue to un-suitable condition during storage (Zahran, 2004). 
APC of any food article isnot a sure indicative for its safety forconsumption, yet it is of supremeimportance in judging the hygienicconditions under which it has beenproduced, handled and stored (Jay, 1997a). Also, APC is considered as index ofsanitary\& quality of foods (Forsythe \&Hayes, 1998). Generally, the high bacterialcounts of examined meat products may bedue to contamination of flesh used formanufacture of these products, howevermincing machines, grinders, equipmentsand knives are considered as the source ofcontamination of meat during processing (ICMSF,1996a). As well as, Addition of certainspices during manufacture of meat productsmay lead to marked increase in bacterialpopulation (Sharaf, 1999).

Total staphylococci count is a good indication of inadequate sanitation and processing as well as the possibility for presence of enterotoxin producing strains as S.aureus (ICMSF, 1996b).

The results recorded in table (2) revealed that the total staphylococci count ranged from $<10$ to $7.8 \times 10^{3}$ with an average value of $4.14 \times 10^{2} \pm 3.89 \times 10^{2} \mathrm{cfu} / \mathrm{g}$ forchicken nuggets; $<10$ to $4.7 \times 10^{3}$ with an average value of $2.69 \times 10^{2} \pm 2.34 \times 10^{2} \mathrm{cfu} / \mathrm{g}$ for chicken burger; $<10$ to $4.7 \times 10^{3}$ with an average value of $2.59 \times 10^{2} \pm 2.34 \times 10^{2} \mathrm{cfu} / \mathrm{g}$ for chicken lunchon.,. lower findings were observed in AL-Dughaym and Altabari (2010); ELHoti, el al., (2011) and Wang et al., (1976b) this high count of staphylococcal sp. Indicate bacterial contamination during packing and handling by the workers.

The high incidence of Staph. spp. organisms inchicken products is an indicative ofunacceptable level of contaminationduring handling (Gad, 2004). Also, thepresence of $S$. aureusin food indicates poorhygiene and improper storage conditions (Gundogan et al., 2005). Kafrelsheikh Vet. Med. J. Vol. 14 No. 1 (2016) 
Moreover, thepresence of $S$. aureusin heat treated foodmay be due to its contamination from foodhandlers, inadequate cleaned equipment orpostprocessing contamination (Duffy et al., 2000). Nearly similar results were obtained by Ahmed (2004).

\section{Enterobactreaceai is a better indicator of unhiygenic conditions:}

Results achieved in Table (3)) revealed that the total Enterobactreacea count ranged from $<10$ to $2 \times 10^{4}$ with an average value of $1.855 \times 10^{3} \pm 1.06 \times 10^{3} \mathrm{cfu} / \mathrm{g}$ forchicken nuggets; $<10$ to $8.3 \times 10^{5}$ with an average value of $4.577 \times 10^{4} \pm 4.1 \times 10^{4}$ for chicken burger $\mathrm{cfu} / \mathrm{g}$; $<10$ to $1 \times 10^{5}$ with an average value of $5.127 \times 10^{3} \pm 4.99 \times 10^{3} \mathrm{cfu} / \mathrm{g}$ forchickenlunchon. Ecoliasmemberof enterobactreacea. E.coli waspreviouslyisolated from chicken meat products by Ahmed (2004), Al-Dughaym and Altabari (2010), Sharaf and Sabra (2012), Awadallah et al. (2014).

The Presence of E.coliin examined samplesindicatedfaecal contamination, potentialfood spoilage and bad sanitary conditionsduring production (Banwart, 1981) as well asfood-borne outbreaks of gastroenteritis.Moreover, the presence of E.coliin food ofanimal origin is considered as indicator offaults during preparation, handling, storageor service (Tebbut, 1999).

Generally, the presence of enterobactreacea in chicken meat products is considered as an indicator for improper handling and unhygienic conditions after slaughtering, de-feathering, and washing fresh chicken carcasses. Our results were agreed with Frazier and Westhoff (1983) and Hashim (2003) while Abd-ELHaffeiz (1999) could not detect it from nuggets. 


\section{Total mold, yeast count:}

Table(4) revealed that the total Mold,yeast count ranged from $2.7 \times 10^{2}$ to $6 \times 10^{5}$ with an average value of $3.07 \times 10^{4} \pm 2.99 \times 10^{4} \mathrm{cfu} / \mathrm{g}$ forchicken nuggets; $4.0 \times 10^{2}$ to $3 \times 10^{5}$ with an average value of $1.598 \times 10^{4} \pm 1.49 \times 10^{4} \mathrm{cfu} / \mathrm{g}$ for for chicken burger; $4.0 \times 10^{2}$ to $3.0 \times 10^{5}$ with an average value of $1.572 \times 10^{4} \pm 1.49 \times 10^{4} \mathrm{cfu} / \mathrm{g}$ chicken lunchon.

According to the legal requirements of Egyptian Organization for Standardization and Quality Control EOSQC, (2005.it is evident that 20, 30 and $20 \%$ of Breast, Nuggets and Wings samples respectively had Staph. aureus above the permissible limit. Presence of Staph. aureus may be attributed to inadequate heat treatment, unhygienic handling practices, use of dirty containers, faulty storage and transportation, so the hands and clothes of employees in the production of chicken meat should be over looked (Duffrenne et al., 2001), nearly similar results recorded by Pepe el al., (2006).

The microbial contamination in chicken samples (20.0\%). Alvarez et al (2002) recorded relatively higher results of mesophiles, S. aureus, colifrom. The author reported that $80 \%$ of chicken burger were an acceptable on the basis of Spain microbiological standards,

Cohen et al (2007) concluded that the highest bacterial counts especially aerobic plat counts and focal coli forms in poultry meat products were recorded in hot season.

The high levels of microbial contamination and occupancy of pathogens reflect the poor hygienic quality of poultry meat under these conditions. 
Bkheet et al (2007) conclude the highest bacterial counts especially aerobic plate counts and fecal coliforms in poultry meat products (chicken burger and chicken nuggets). The mesospheric counts were $2.6 \times 10^{5}$ and $3.1 \times 10^{5}$ respectively.

In conclusion, Rose et. al., (2002) suggested that application of food safety and inspection service (FSIS) and HACCP systems one effective in controlling the contamination of poultry products with human disease causing bacteria, an these performance standards an based on prevalence of salmonella as determined from the FSIS'S nationwide microbial baseline studies and are expressed in term of the maximum number of salmonella, positive samples that one allowed in a given sample set. Also found that salmonella prevalence in most of the product Cato genies was lower of the implementation of HACCP than in pre HACCP baseline studies and surveys conducted by the FSIS.

\section{REFERENCES}

- Abd EL-Magied, Valaa, K.A.; Hassan, M. A.; Shaltout, F.A. and Amada, Hanan, M.(2009): Occurrence of psychrotrophic pathogens in chicken meat products. M.V.Sc. (Meat hygiene) Thesis, Fac. Vet. Med., Benha Uni.

- Abdel-Haffeiz, E.M. (1999): Application of HACCP system in chicken nuggets to produce safety and high quality products. Alex. J. Vet. Sci. 115 (4).

- Aberle,E.D.,Forrest, J., Gerrard, D.E., Mills, E.W. (2001): Principles of Meat Science ( $4^{\text {th }}$ Ed). Hunt Publishing Co., Kendall, USA. 
- Ahmed, A.F. (2004): Studies on cooked meat and chicken products. PhD., Thesis (Meat Hygiene), Fac. Vet. Med., Zagazig Univ., Benha Branch.

- AL-Dughaym, A.M. andAltabari, G.F. (2010): Safety and quality of some chicken meat products in AL-Ahsa markets, Saudia Arabia. Saudi. Biol. Sci. 17(1): 37-42.

- Alvarez-Astorga M, Apita R, Alonso-Calleja C, MorenoB and Del Camoni GM (2002): Microbiological quality of retail chicken byproducts in Spain. Meat Science, 62: 45-50.

- APHA (1992): Compendium of methods for microbiological examination of food. $3^{\text {rd }}$ Ed. American public health association, Washington DC.

- Awadallah, M.A.I., Ahmed, H.A., Merwad, A. M. (2014): Prevalence of non- O157 shiga toxin-producing Escherichia coli and Enterotoxigenic staphylococci in ready-to-eat meat products, handlers and consumers in Cairo, Egypt. Global Veterinaria 12 (5):692-699.

- AyçiçekH, et al., (2004a): Assessment of the microbiological quality of meals sampled at the meal serving units of a military hospital in Ankara, Turkey. Food Control ;15:379-384.

- Banwart, G.J.(1981):Indicator organisms in:Basic food microbiology. $2^{\text {nd }}$ Ed. Avi. Publishing Co., West port, onnecticut, USA.

- Beckers, S.A. (1998): "More U.S. consumers prefer chicken"MissetWorld Poultry, 9: 20-21. 
- Bkheet, A. A.; Rezk,M. SH. and Mousa, M.M. (2007): Study on the microbiological content of local manufactured poultry meat products in El-Bahira governorate. Assuit Vet. Med. J. 53 no. 112:115-125.

- Carvalho, A.C.F.B., Cortez, A.L.L., Salotti, B.M., Burger, K.P., Vidal-n Martins, A.M.C. (2005): Preasence of mesophilicpsychophilic and coliform microorganism in different samples of poultry products. Arquivos do InstitutoBiologico (Sao Paulo).,3(72): 303-307. 24.

- Cohen N, Ennaji H, Bouchrif B and Hassar MH (2007): Comparative study of microbiological quality of raw poultry meat at various seasons and for different slaughtering processes in Casablanca (Morocco). Poultry Science Association, 16: 502-508.

- Cruickshank, R., J.P. Duguid, B.D. Marmion and R.H.A Swain, (1975): Medical microbiology. The practice of medical microbiology. V11, 12t h Ed Churchil. Living Stone, Edinburgh Duffy, G., Kilbride, .heridan, J.J., Blair, I.S., McDowell, D.A. 2000. A membrane immuno-flouresecnt viability aining technique for the detection of Salmonella spp. From fresh and processed meat samples. J. Appl. Microbiol., 89(4):587-594.

- Duffrene, J.; Ritmeester, W.; Delfgou, E.; Leusden, F. and DeJonge, R. (2001): Quantification of the contamination of chicken and chicken products in Netherlands with salmonella. J. Food Prote., 64 (4): 538-541.

- Egyptian Organization for Standardization and Quality Control (EOSQC) (2005): Standard specification No. 3493 for heat treated chicken meat. 
- ELHoti, F.A.I. (2011): Effect of batter formulations on the quality of coated chicken meat products. Ph.D. Thesis (Meat Hygiene) Vet. Sc.Fact., of Vet. Med. Cairo Univ.

- EL-Shora, S.E.(1990): Studied on the sanitary status of Kalyobia meat poultry and fish cool stores. M.V.Sc. Thesis (Meat Hygiene), Fac. of Vet. Med., Benha Uni.

- Forsythe, S. J. and Hayes, P. R., (1988): Food Hygiene, Microbiology and HACCP. A Chapman and Hall Food Science Book. Aspen

- Frazier, W.C., Westhoff, D.C. (1983): Food Microbiology. 3rd edn., Tata McGraw Hill Publ. Co., New Delhi, India.

- Gad, M.A. (2004): Microbiological evaluation of poultry meat and its products. M.V.Sc., Thesis Meat hygiene, Fac. Vet. Med., Sadat branch MinofyiaUniv.

- GuaranTek Analytical Laboratories (2003): Microbiology. Web page article.

- Gundogan, N., Citak, S., Yucel, N., Devren, A. (2005): A note on the incidence and antibiotic resistance of $S$. aureusisolated from meat and chicken samples. Meat Sci., 69(4): 807-810.

- Hashim, E.S.V. (2003): Aerobic and anaerobic enterotoxigenic bacteria in ready-to-eat food Ph.D. Thesis, Fac. Vet. Med. Benha Univ. 
- Health Protection Agency.(HPA), (2004): Food Sampling. National microbiological food studies carried out by the Health Protection Agency and the Local Authorities Co-ordinators of Regulatory Services 243-249(27).

- International Commission on Microbiological Specification for Foods (ICMSF), (I978a): Microbial ecology of foods. Their significance and methods of enumeration $2^{\text {nd }}$ Ed. Univ. of Toronto Press, Toronto and Buffalo, Canada.

- International Commission on Microbiological Specification for Foods (ICMSF), (I978b): Microorganisms in food Vol. 1 Univ. of Toronto Press, Toronto and Buffalo, Canada.

- Jay, J.M. (1972): Mechanism and detection of microbial spoilage on meat at low temperature. J. Milk and Food Technol35:46-47.

- Koburger, J.A. and B.Y. Farahat, (1975): Fungi in foods. Comparison of media to enumerate yeast and mould. J. Milk and Food Technol., 38: 455-468

- NACMCF (National Advisory Committee on Microbiological Criteria for Foods) (1997): HAZARD Analysis and Critial Control Point Principles and Application Guidelines. Journal of Food Protection 61, 762-775.

- Osman, M.S. (2001): Quality assurance of locally dressed broiler's cuts and their products. Ph.D. Thesis. Fac. Vet. Med. Cairo Univ. 
- Pepe, O.; Blaiotta, G.; Bucci, F.; Anastasia, M.; Aponte, M. and Villani, F. (2006): Staphylococcus aureus and Staphylococcal enterotoxin A. in breaded chicken products: Detection and behavior during the cooking process. Applied Environ. Microbiol., 72 (11): 7057-7062.

- Potter, N. (2001). Food Science. 4th Ed., The AVI publishing Co., Inc., New York, USA.

- Quinn, P.J.; B.K. Markey, M.E. Carter, W.J.C. Donnelly, F.C. Leonard and D. Mnguine, (2002): Veterinary Microbiology and Microbial Diseases. $1^{\text {st }}$ Published Blackwell Science ltd.

- ROSE ET AL., (2002): Testing for Salmonella in raw meat and poultry products collected at federally inspected establishments in the United States, 1998 through 2000,J Food Prot. 2002 Jun;65(6):937-47.

- Sahoo, J., Samoon, A.H., Sapcota, D. (1996): Recent developments in further processed poultry meat products. Indian Food Indust., 15 (2):30-36.

- Shaltout, F.A. (2006): Microbiological aspect of semi-cooked chicken meat products. Benha, Vet. Med. J., 13(2): 15-25.

- Sharaf, E.M., Sabra, S.M. (2012): Microbiological loads for some types of cooked chicken meat products at Al-Taif Governorate, KSA. World Applied Sciences Journal, 17(5):593- 597.

- Sharaf, S.H. (1999): Bacteriological studies on meat and meat products with special reference to salmonella and shigella serotypes. Ph.D. Thesis (meat hygiene), Fac. Vet. Med. Moshtohor, Zahazig University (Benha Branch). 
- Shedeed, N.A. (1999): Evaluation of microwave cooking of chicken meat. M.V. Sci.Thesis, Fac. of Agri., Cairo Univ.

- Sofroni, E.; Gary, D. A.; Bixing, H.; Narelle, F. and Stuttard, E. (2008): Bacteriological profile of raw, frozen chicken nuggets. J. Food Prot., 71(3):613-615.

- Tebbut, G. M. 1999. Microbiological contamination of cooked meats and environmental site in premise selling both raw and cooked meat products. Inter. J. Environm. Health Research 3(4):209-216

- USDA (2012). Introduction to the microbiology of food Processing. United States, http://www.fsis.usda.gov/shared/ PDF/SPN_Guidebook _Microbiology.pdf.

- WHO (2002). A Guide to Healthy Food Markets. Switzerland, http://www.who.int/foodsafety/publications/capacity/healthymarket_g uide.pdf

- Zahran, D.A. 2004. Using gamma irradiation as an option for controlling bacteria contaminating some foods of animal origin. $\mathrm{PhD}$., Thesis of Meat Hygiene, Faculty Veterinary Medicine, Zagazig University (Banha Branch), Banha, Egypt.

- Zaki, Nadia,Y. 1994. Microbiological problems of processing, handling and storage of poultry meat. M. V. Sci Thesis, Meat Hygiene, Fac. Vet. Med. Benha Univ. 


\section{تقييي الحالة الصحية لمنتجات الدواجن المصنعة محلياً}

\section{نادر يحيي مصطفي يحيي' ، خالد شوقي طلبة' ، رانيا حسن إسماعيل الثهاوي” قسم الرقابة الصحية على الأغنية ـمعه بحوث صحة الحيوان - مركز البحوث الزراعية. قسم الرقابة الصحية على الأغنية - كلية الطب البيطرى - جامعة كفر الشبيخ .}

تعتبر الـواجن ومنتجاتهـا مـن الأغذيـة المفضلة لـدي جمهور الـستهلكين لاحتو ائها علي البروتين ذات القيمة الغذائية العالية بالإضافة لسهولة هضمها. وقد تتعرض الدو اجن ومنتجاتها أثناء تجهيز ها ونقلها للتلوث بمختلف الميكروبات التي تؤدي إلي فسادها، بالإضافة إلي أنها في هذه الحالـة

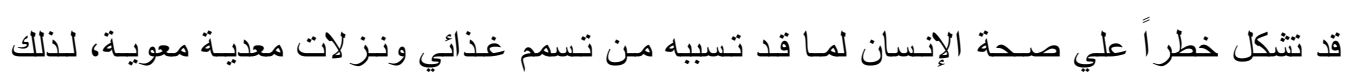
استهدفت الرسالة الوقوف علي الحالة الصحية الظاهرية و الميكروبية لمنل هذه المنتجات. اثنتلت الدر اسة علي فحص عدد ، عينـة عشو ائياً من منتجـات لحوم الدو اجن النصف

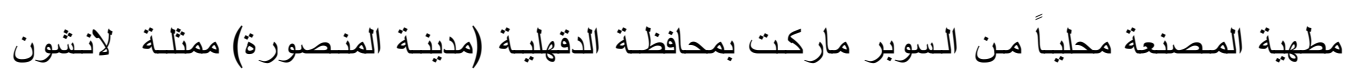
الاجاج، برجر الدجاج، ناجيتس الدجاج (•r عينة لكل منهم). نم اختبار العينات ميكروبياً لثقييم مدي جودة هذه المنتجات (هذه العينـات ، ج عينـة تم اختبار هـا وتحليلها للميكروبـات الآتيـة :العدد الكلي للبكتريا الهو ائية و الميكروبـات المعويـة و الفطريـات و الخمـائر وعد العدد الكلي للميكروب الكروي الذهبي وقد دلت النتائج علي ان اعلي منوسط للعد البكتيـري كـان في منتج لانشون الدجاج و اقل منوسط عدد بكتيرب كـان في منتج النـاجيتس وذلك كمنـال للعد الكلي للبكتيريـا الهو ائيسة كالتـالي

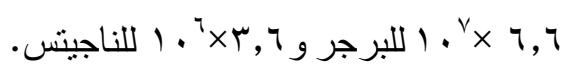
هذا وقد تم مناقثة النتائج و التوصيات اللازمـة وذلك للحد مـن وجـود هذه الميكروبـات فى منتجات اللحوم للحد من حالات التسمم الغذائي. 